Columbia Law School

Scholarship Archive

\title{
Supreme Court Amicus Brief of 22 Corporate Law Professors, Mark Janus v. American Federation of State, County and Municipal Employees, Council 31, et al, No. 16-1466
}

\author{
John C. Coates, IV \\ Harvard Law School, jcoates@law.harvard.edu \\ Lucian A. Bebchuk \\ Harvard Law School, bebchuk@law.harvard.edu \\ John C. Coffee Jr. \\ Columbia Law School, jcoffee@law.columbia.edu \\ Bernard S. Black \\ Northwestern University Pritzker School of Law, Bernard_Black@ssrn.com \\ Lawrence A. Hamermesh \\ Widener University Delaware Law School \\ Follow this and additional works at: https://scholarship.law.columbia.edu/faculty_scholarship

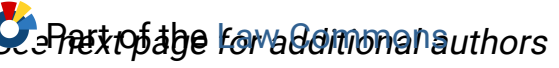

\author{
Recommended Citation \\ John C. Coates, IV, Lucian A. Bebchuk, John C. Coffee Jr., Bernard S. Black, Lawrence A. Hamermesh, \\ James D. Cox, Marcel Kahan, Reinier Kraakman, Jeffrey N. Gordon, Ronald J. Gilson, Vikramaditya S. \\ Khanna, Michael Klausner, Henry Hansmann, Donald C. Langevoort, Brian J. Quinn, Michal Barzuza, Mira \\ Ganor, Edward B. Rock, Mark J. Roe, Helen S. Scott, Holger Spamann \& Randall S. Thomas, Supreme \\ Court Amicus Brief of 22 Corporate Law Professors, Mark Janus v. American Federation of State, County \\ and Municipal Employees, Council 31, et al, No. 16-1466, (2017). \\ Available at: https://scholarship.law.columbia.edu/faculty_scholarship/2076
}

This Working Paper is brought to you for free and open access by the Faculty Publications at Scholarship Archive. It has been accepted for inclusion in Faculty Scholarship by an authorized administrator of Scholarship Archive. For more information, please contact scholarshiparchive@law.columbia.edu. 


\section{Authors}

John C. Coates, IV; Lucian A. Bebchuk; John C. Coffee Jr.; Bernard S. Black; Lawrence A. Hamermesh; James D. Cox; Marcel Kahan; Reinier Kraakman; Jeffrey N. Gordon; Ronald J. Gilson; Vikramaditya S. Khanna; Michael Klausner; Henry Hansmann; Donald C. Langevoort; Brian J.M. Quinn; Michal Barzuza; Mira Ganor; Edward B. Rock; Mark J. Roe; Helen S. Scott; Holger Spamann; and Randall S. Thomas 
No. $16-1466$

IN THE

Supreme Court of the afmited States

MARK JANUS,

Petitioner,

$v$.

AMERICAN FEDERATion Of State, County, AND

Municipal Employees, Council 31, ET AL.,

Respondents.

On Writ of Certiorari to the United States Court of Appeals

for the Seventh Circuit

BRIEF OF CORPORATE LAW PROFESSORS

AS AMICI CURIAE IN SUPPORT

OF NEITHER PARTY

ANNA-ROSE MATHIESON

Counsel of Record

BEN FEUER

CALIFORNIA APPELLATE LAW GROUP LLP

96 Jessie Street

San Francisco, CA 94105

(415) 649-6700

annarose@calapplaw.com

Attorneys for Amici Curiae 
TABLE OF CONTENTS

\section{Page}

INTEREST OF AMICI CURIAE .............................. 1

INTRODUCTION AND SUMMARY OF

ARGUMENT …....................................................... 4

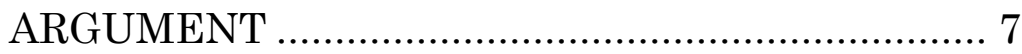

I. Individual Shareholders Generally Have

No Right to "Opt Out" or Otherwise

Control the Use of Capital They Invest in

a Corporation.

II. Most Individual Shareholders Cannot Indirectly Influence the Use of Their Invested Capital for Political Expression. . 11

A. Shareholders do not typically have the right to compel a corporation to repurchase or find a buyer for their shares.

B. Shares of most corporations are not traded on public markets, and finding buyers for such shares is difficult or impossible....

C. Stock sales cannot generally be used to prevent, deter, or influence the political activities of publicly traded companies.

D. Shareholder voting rights are not generally useful for directing or influencing specific corporate actions. 
ii

\section{TABLE OF CONTENTS (continued)}

\section{Page}

III. Many Individuals Are Effectively

Compelled to Maintain Investments in Companies Whose Political Expenditures

They Do Not Know and Cannot Control. ... 24

A. Most beneficial owners of public corporations are individuals who own through institutions such as mutual funds and pension funds.

B. Individuals who own stock through intermediaries do not have the right to direct the sale or votes of their shares. ..................... 28

C. Individual investors have little prudent choice other than investing through institutions to achieve diversification.

D. Institutional intermediaries are not generally required to track or disclose to their beneficiaries the political activities of the companies in which they invest....... 34

E. Most individual investors are in practice compelled to maintain investments in companies that can engage in political expenditures with which the investors disagree. 
iii

TABLE OF CONTENTS (continued)

\section{Page}

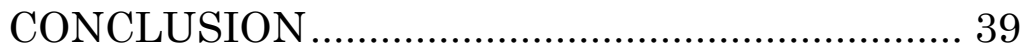




\section{TABLE OF AUTHORITIES}

\section{Page(s)}

\section{Cases}

Abood v. Detroit Bd. of Ed.,

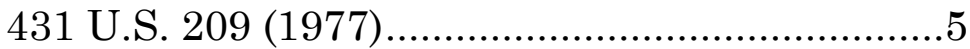

Austin v. Mich. State Chamber of Commerce, 494 U.S. 652 (1990)............................................

Barnes v. State Farm Mut. Auto. Ins. Co., 20 Cal. Rptr. 2d 87 (Cal. Ct. App. 1993)

Basic Inc. v. Levinson, 485 U.S. 224 (1988)

Bd. of Regents of Univ. of Wisconsin Sys. $v$. Southworth, 529 U.S. 217 (2000) .5

Blaustein v. Lord Baltmore Capital Corp., 84 A.3d 954 (Del. 2014)

CA, Inc. v. AFSCME Emps. Pension Plan, 953 A.2d 227 (Del. 2008)

Case v. N.Y. Cent. R.R. Co., 204 N.E.2d 643 (N.Y. 1965) 10

Citizens United v. Fed. Election Comm'n, 558 U.S. 310 (2010).

Consol. Edison Co. of N.Y., Inc. v. Pub. Serv.

Comm'n of N.Y., 447 U.S. 530 (1980).

F.D.I.C. v. Wheat, 970 F.2d 124 (5th Cir. 1992) 
V

\section{TABLE OF AUTHORITIES (continued)}

\section{Page(s)}

Fed. Election Comm'n v. Mass. Citizens for

Life, Inc.,

479 U.S. 238 (1986).........................................

Finley v. Superior Court, 96 Cal. Rptr. 2d 128 (Cal. Ct. App. 2000) ............10

First Nat'l Bank v. Bellotti, 435 U.S. 765 (1978)

Gorman v. Salamone, 2015 WL 4719681 (Del. Ch. July 31, 2015) ..........8

Halliburton Co. v. Erica P. John Fund, Inc., 134 S.Ct. 2398 (2014)

In re Appraisal of Dell Inc., 2015 WL 4313206 (Del. Ch. July 13, 2015)

Int'l Assoc. of Machinists \& Aerospace Workers v. Fed. Election Comm'n, 678 F.2d 1092 (D.C. Cir. 1982).

Jana Master Fund, Ltd. v. CNET Networks, Inc., 954 A.2d 335 (Del. Ch. 2008).

Kamin v. Am. Express Co., 54 A.D.2d 654 (N.Y. App. Div. 1976)......................9

Keller v. State Bar of California, 496 U.S. 1 (1990) .5

McConnell v. Fed. Election Comm'n, 540 U.S. 93 (2003)

Miller v. Am. Tel. \& Tel. Co., 507 F.2d 759 (3d Cir. 1974) 
vi

\section{TABLE OF AUTHORITIES (continued)}

\section{Page(s)}

Nixon v. Blackwell, 626 A.2d 1366 (Del. 1993)....................................12

Orman v. Cullman, 794 A.2d 5 (Del. Ch. 2002)

Pipefitters Local Union No. 562 v. United

States, 407 U.S. 385 (1972).............................................

Shlensky v. Wrigley, 237 N.E.2d 776 (Ill. App. Ct. 1968) ......................10

Sinclair Oil Corp. v. Levien, 280 A.2d 717 (Del. 1971)

Sullivan v. Hammer, 1990 WL 114223 (Del. Ch. Aug. 7, 1990)

Theodora Holding Corp. v. Henderson, 257 A.2d 398 (Del. Ch. 1969). 9,10

United States v. Int'l Union UAW-CIO, 352 U.S. 567 (1957)...........................................

\section{STATUTES}

Del. Code Ann. Title 8, § 141(a)...............................

Del. Code Ann. Title 8, § 151(b)...............................12

Del. Code Ann. Title 8, § 220 ..................................17

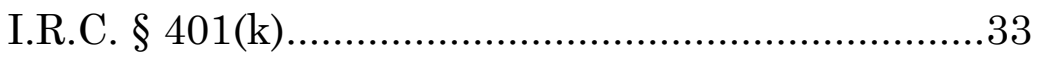

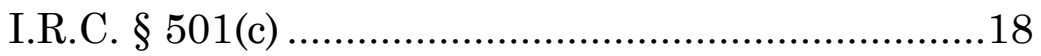


vii

\section{TABLE OF AUTHORITIES (continued)}

\section{Page(s)}

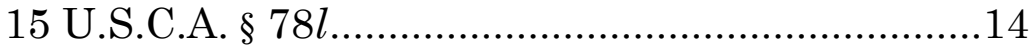

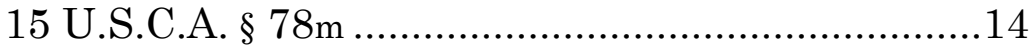

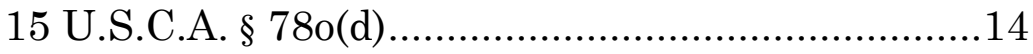

Other AUthorities

WiLliam T. Allen ET AL., COMMENTARIES AND CASES ON THE LAW OF BUSINESS Organization (Aspen Publishers, 4th ed. 2012)

Private Equity: Top States \& Districts, AMERICAN INVESTMENT COUNCIL, http://www.investmentcouncil.org/privateequity-at-work/education/private-equitytop-states-districts/ (last visited Dec. 1, 2017)

Aon HewitT, 2014 Universe Benchmarks HighLIGHTS (2014), available at http:// tinyurl.com/n964gmq.

Ian Ayres \& Quinn Curtis, Beyond Diversification, 124 YALE L.J. 1476 (2015) ....32, 33

Stephen M. Bainbridge, Corporation LaW AND ECONOMICS (Foundation Press, 2002).

Brad M. Barber \& Terrance Odean, Trading Is Hazardous to Your Wealth: The Common Stock Investment Performance of Individual Investors, 55 J. FIN. 773 (2000). 
viii

\section{TABLE OF AUTHORITIES (continued)}

\section{Page(s)}

Lucian A. Bebchuk \& Robert J. Jackson, Jr., Corporate Political Speech: Who Decides?, 124 HARV. L. REV. 83 (2010)..........................16, 18

Jonathan Berk \& Peter DeMarzo, Corporate Finance (Pearson, 3d ed. 2014)

Marshall E. Blume \& Donald B. Keim, The Changing Nature of Institutional Stock Investing (Nov. 12, 2014 working paper), available at http://tinyurl.com/qhqskrp

BOARD OF GOVERNORS OF THE FEDERAL Reserve System, Financial Accounts of THE United STATES: Flow OF Funds, BALANCE SHEETS, AND INTEGRATED MACROECONOMIC ACCOUNTS (2015), available at http://www.federalreserve.gov /releases/z1/current/z1.pdf

BRIGHTSCOPE \& INVESTMENT COMPANY InstituTe, The BRIGHTSCOPE / ICI DEFINED Contribution Plan Profile: A Close LoOK AT 401(K) Plans (2014), available at http://www.ici.org/pdf/ppr_14_dcplan_ profile_401k.pdf

Victor Brudney, Business Corporations and Stockholders' Rights Under the First Amendment, 91 YALE L.J. 235 (1981) 
ix

\section{TABLE OF AUTHORITIES (continued)}

\section{Page(s)}

Kimberly Burham et al., Ownership of Mutual Funds, Shareholder Sentiment, and Use of the Internet, 2013, ICI RES. PERSP., Oct. 2013, available at https:// www.ici.org/pdf/per19-09.pdf.

Robert C. Clark, Agency Costs Versus Fiduciary Duties, in PRINCIPALS AND Agents: The Structure of Business (John W. Pratt \& Richard J. Zeckhauser eds., Harvard Business School Press 1985) .......8, 9

Robert Charles Clark, Corporate LaW (Little, Brown \& Co., 1986).....................................7

John C. Coates IV, "Fair Value" as an Avoidable Rule of Corporate Law: Minority Discounts in Conflict Transactions, 147 U. PA. L. REv. 1251 (1999)

John C. Coates IV, The Powerful and Pervasive Effects of Ownership on $M \& A$ (June 1, 2010), available at http://ssrn.com/ abstract $=1884157$.

John C. Coates IV, Thirty Years of Evolution in the Roles of Institutional Investors in Corporate Governance, in RESEARCH HANDBOOK ON SHAREHOLDER POWER (Jennifer G. Hill \& Randall S. Thomas eds., Edward Elgar 2015) $14,21,25$ 


\section{TABLE OF AUTHORITIES (continued)}

\section{Page(s)}

CommitTee on Disclosure of CoRPorate Political SPEnding, Petition FOR RULEMAKING (Aug. 3, 2011), available at http://sec.gov/rules/petitions/2011/petn4637.pdf.

K.J. Martijn Cremers \& Antti Petajisto, How Active Is Your Fund Manager? A New Measure That Predicts Performance, 22 REV. Fin. STUd. 3329 (2009)

Aswath Damodaran, Annual Returns on Stock, T.Bonds and T.Bills: 1928-Current, http://pages.stern.nyu.edu/ adamodar/Ne w_Home_Page/datafile/histretSP.html (last updated Jan. 5, 2017)

Phil Edwards et al., Defined Contribution Plan Success Factors, DCIIA, May 2015, available at https://tinyurl.com/yd9vgfmt.

Vyacheslav Fos \& Margarita Tsoutsoura, Shareholder Democracy in Play: Career Consequences of Proxy Contests, 114 J. FIN. ECON. 316 (2014).

Charles Fried et al., Lobbying Law in the Spotlight: Challenges and Proposed Improvements, 63 ADMIN. L. REV. 419 (2011) 
xi

\section{TABLE OF AUTHORITIES (continued)}

\section{Page(s)}

Nickolay Gantchev, The Costs of Shareholder Activism: Evidence from a Sequential Decision Model, 107 J. FIn. ECON. 610 (2013)

Sarah Holden et al., 401(k) Plan Asset Allocation, Account Balances, and Loan Activity in 2012, 19 ICI REs. PersP. Dec. 2013

Clifford G. Holderness, The Myth of Diffuse Ownership in the United States, 22 REV. FIN. STUD. 1377 (2009)

INTERNAL REVENUE SERVICE, 2016 STATISTICS of Income, 2016 Tax Statistics (2016), available at https://www.irs.gov/pub/irssoi/16taxstatscard.pdf

Retirement Savings Contributions Credit (Saver's Credit), INTERNAL REvEnUe SERVICE, https://www.irs.gov/RetirementPlans/Plan-Participant,-Employee/ Retirement-Savings-Contributions-SaversCredit (last updated Oct. 26, 2017) .................31, 32

John Koeplin et al., The Private Company Discount, 12 J. APPL. CoRP. Fin. 94 (2000) 15

REINiER KraAkMan, ET AL., The ANatomy of CORPORATE LAW (Oxford $2 \mathrm{~d}$ ed. 2009) 8,22 
xii

\section{TABLE OF AUTHORITIES (continued)}

\section{Page(s)}

Christian Leuz et al., Why Do Firms Go Dark?

Causes and Economic Consequences of Voluntary SEC Deregistrations, $45 \mathrm{~J}$. ACCOUNT. ECON. 181 (2008)

Martin Lipton \& Steven A. Rosenblum, A New System of Corporate Governance: The Quinquennial Election of Directors, 58 U. CHI. L. REV. 187 (1991)

Petro Lisowsky \& Michael Minnis, Accounting Choices and Capital Allocation: Evidence from Large Private U.S. Firms (Dec. 2016 working paper), available at http://ssrn.com/abstract $=2373498$

Burton G. Malkiel, Returns from Investing in Equity Mutual Funds 1971 to 1991, 50 J. FIN. 549 (1995)

Harry M. Markowitz, Portfolio Selection, 7 J. FIN. 77 (1952)

Alicia H. Munnell et al., Defined Contribution Plans in the Public Sector: An Update, 37 State and Local Pension Plans (April 2014), available at http://crr.bc.edu/wpcontent/uploads/2014/04/SLP_37_508rev. $\mathrm{pdf}$ 
xiii

\section{TABLE OF AUTHORITIES (continued)}

\section{Page(s)}

Alicia H. Munnell et al., What's the Tax Advantage of 401(k)s?, CENTER FOR RETIREMENT RESEARCH AT BOSTON COLlege, Feb. 2012, available at http:// tinyurl.com/ndjkdwh....................................32, 37

Andrea Murphy, America's Largest Private Companies 2014, ForBes (Nov. 5, 2014), available at http://www.forbes.com/sites/ andreamurphy/2014/11/05/americaslargest-private-companies-2014/

Oklahoma Public Employees Retirement System, The New Defined Contribution System: Understanding the Basics, http:// www.opers.ok.gov/dc-basics (last visited Dec. 1, 2017)

Richard A. Posner, Economic Analysis of

LAW (Aspen Publishers, 8th ed. 2011)

BRIAN REID ET AL., 2015 INVESTMENT

COMPANY FACT BOOK (Investment Company Institute, 5th ed. 2015) available at http://www.ici.org/pdf/2015_factbook.pdf ..21, 27

Benjamin I. Sachs, Unions, Corporations, and Political Opt-Out Rights After Citizens United, 112 CoLUM. L. REV. 800 (2012). 
xiv

\section{TABLE OF AUTHORITIES (continued)}

\section{Page(s)}

Gary C. Sanger \& John J. McConnell, Stock Exchange Listings, Firm Value, and Security Market Efficiency: The Impact of NASDAQ, 21 J. Fin. Quant. ANAL. 1 (1986)

An Introduction to 529 Plans, SECURITIES AND

EXCHANGE COMMISSION, http://www.sec. gov/investor/pubs/intro529.htm (last modified Jan. 6, 2014) .

OFFICE OF COMPLIANCE INSPECTIONS AND EXAMINATIONS, SECURITIES AND EXCHANGE COMMission, NATIONAL EXAM RisK AlERT (Sept. 29, 2011), available at http:// www.sec.gov/about/offices/ocie/riskalertmastersubaccounts.pdf

Office of Economic Analysis, Securities AND ExChANGE Commission, STUdy OF SARBANES-OXLEY ACT OF 2002 SECTION 404 INTERNAL CONTROL OVER FINANCIAL REPORTING REQUIREMENTS (Sept. 2009), available at http://www.sec.gov/news/ studies/2009/sox-404_study.pdf.

Mark A. Stach, An Overview of Legal and Tactical Considerations in Proxy Contests: The Primary Means of Effecting Fundamental Corporate Change in the 1990s, 13 Geo. Mason U. L. Rev. 745 (1991) 
$\mathrm{XV}$

\section{TABLE OF AUTHORITIES (continued)}

\section{Page(s)}

Leo E. Strine, Jr. \& Nicholas Walter, Conservative Collision Course?: The Tension Between Conservative Corporate Law Theory and Citizens United, 100 CORNELL L. REV. 335 (2015)

STRS Ohio, DC Plan, https://www.strsoh.org/ aboutus/impact/dc.html (last visited Dec. 1, 2017)

Randall S. Thomas \& Catherine T. Dixon, ARANOW \& EISHORN ON PROXY CONTESTS For CORPORATE CONTROL (3d ed. 2001 supp.)

Anne Tucker, Flawed Assumptions: A Corporate Law Analysis of Free Speech and Corporate Personhood in Citizens United, 61 CASE W. RES. L. REV. 497 (2010).

Anne Tucker, Retirement Revolution: Unmitigated Risks in the Defined Contribution Society, 51 Hous. L. REV. 153 (2013)

Jonathan Weisman, G.O.P. Error Reveals Donors and the Price of Access, N.Y. TIMES, Sept. 24, 2014, at A15, available at http://www.nytimes.com/2014/09/25/us/rep ublicans-corporate-donors-governors. html?_r=0

Adam Winkler, Beyond Bellotti, 32 Loy. L.A. L. REV. 133 (1998) 
xvi

\section{TABLE OF AUTHORITIES (continued)}

\section{Page(s)}

Listed Domestic Companies, Total, THE WORLD BANK, http://data.worldbank.org/ indicator/CM.MKT.LDOM.NO (last visited

Dec. 1, 2017)

ZiCKLIN CENTER FOR BUSINESS ETHICS

RESEARCH AT THE WHARTON SCHOOL OF THE Univ. of Pennsylvania, The 2015 CPAZicklin INDEX OF CORPORATE POLITICAL Disclosure AND ACCOUNTABILITY (Center for Political Accountability 2015), available at http://tinyurl.com/out9bfj 


\section{BRIEF OF CORPORATE LAW PROFESSORS AS AMICI CURIAE IN SUPPORT OF NEITHER PARTY}

The undersigned corporate law professors respectfully submit this brief as amici curiae in support of neither party. ${ }^{1}$

\section{INTEREST OF AMICI CURIAE}

Amici have no personal stake in the outcome of this case; their interest is in assisting the parties and the Court in understanding corporate law and the rights of shareholders, insofar as that law and those rights are relevant to the questions presented in this case. Joining in this brief as amici are the following twenty-two law professors, whose research and teaching have focused on corporate law:

John C. Coates IV, John F. Cogan, Jr. Professor of Law and Economics, Harvard Law School, and Visiting Professor of Finance, Harvard Business School

Michal Barzuza, Nicholas E. Chimicles Research Professor of Business Law and Regulation, University of Virginia Law School

Lucian A. Bebchuk, William J. Friedman and Alicia Townsend Friedman Professor of Law, Economics,

${ }^{1}$ Pursuant to Rule 37.6, amici state that no counsel for a party authored this brief in whole or in part, and no counsel or party made a monetary contribution intended to fund the preparation or submission of this brief. No person other than amici curiae or their counsel made a monetary contribution to the preparation or submission of the brief. Pursuant to Rule 37.3(a), all appropriate parties have filed letters granting blanket consent to the filing of amici curiae briefs. 
and Finance, and Director of the Program on Corporate Governance, Harvard Law School

Bernard S. Black, Nicholas D. Chabraja Professor, Northwestern University Law School and Kellogg School of Management

John C. Coffee, Jr., Adolf A. Berle Professor of Law and Director of the Center on Corporate Governance, Columbia Law School

James D. Cox, Brainerd Currie Professor of Law, Duke University School of Law

Mira Ganor, Judge Solomon Casseb, Jr. Research Professor in Law, University of Texas School of Law

Ronald J. Gilson, Marc and Eva Stern Professor of Law and Business, Columbia Law School, and Charles J. Meyers Professor of Law and Business, Emeritus, Stanford Law School

Jeffrey N. Gordon, Richard Paul Richman Professor of Law and Co-Director, Richman Center for Business, Law \& Public Policy, Columbia Law School

Lawrence Hamermesh, Emeritus Professor, Widener University Delaware Law School, and Executive Director, University of Pennsylvania Institute for Law and Economics

Henry B. Hansmann, Oscar M. Ruebhausen Professor of Law, Yale Law School

Marcel Kahan, George T. Lowy Professor of Law, New York University School of Law

Vikramaditya S. Khanna, William W. Cook Professor of Law, University of Michigan Law School

Michael Klausner, Nancy and Charles Munger 
Professor of Business and Professor of Law, Stanford Law School

Reinier H. Kraakman, Ezra Ripley Thayer Professor of Law, Harvard Law School

Donald C. Langevoort, Thomas Aquinas Reynolds Professor of Law, Georgetown University Law Center

Brian JM Quinn, Associate Dean for Experiential Learning and Associate Professor of Law, Boston College Law School

Edward B. Rock, Professor of Law and Director, Institute for Corporate Governance \& Finance, New York University School of Law

Mark J. Roe, David Berg Professor of Law, Harvard Law School

Helen S. Scott, Professor of Law and Co-Director of the Leadership Program on Law and Business, New York University School of Law

Holger Spamann, Professor of Law, Harvard Law School

Randall S. Thomas, John S. Beasley II Professor of Law and Business, Vanderbilt Law School 


\section{INTRODUCTION AND SUMMARY OF ARGUMENT}

Most individual shareholders cannot obtain full information about a corporation's speech or political activities, even after the fact, nor can most shareholders prevent their savings from being used for political activity with which they disagree. These often-misunderstood points of corporate law are relevant to this case in two ways.

First, this Court has often looked to the rights of corporate shareholders in determining the rights of union members and non-members to control the union's use of their funds for political spending, and vice versa. ${ }^{2}$ In doing so, the Court has sometimes assumed that if shareholders disapprove of corporate political expression, they can easily sell their shares or exercise control over corporate spending. ${ }^{3}$ As explained in this brief, that assumption is mistaken.

\footnotetext{
2 E.g., Citizens United v. Fed. Election Comm'n, 558 U.S. 310, 343-44 (2010); McConnell v. Fed. Election Comm'n, 540 U.S. 93, 325 (2003) (Kennedy, J., concurring \& dissenting), overruled in part by 558 U.S. 310; Austin v. Mich. State Chamber of Commerce, 494 U.S. 652, 709-10 (1990) (Kennedy, J., dissenting), overruled by 558 U.S. 310; Fed. Election Comm'n v. Mass. Citizens for Life, Inc., 479 U.S. 238, 247 (1986); First Nat'l Bank v. Bellotti, 435 U.S. 765, 794 n.34 (1978); Pipefitters Local Union No. 562 v. United States, 407 U.S. 385, 401-02, 406-08 (1972); United States v. Int'l Union UAW-CIO, 352 U.S. 567, 585 (1957).

${ }^{3}$ E.g., Citizens United, 558 U.S. at 370; McConnell, 540 U.S. at 275 (2003) (Thomas, J., concurring); Austin, 494 U.S. at 70910 (Kennedy, J., dissenting); Consol. Edison Co. of N.Y., Inc. $v$. Pub. Serv. Comm'n of N.Y., 447 U.S. 530, 555 (1980) (Blackmun, J., dissenting); Bellotti, 435 U.S. at 794 n.34; see also Int'l Assoc. of Machinists \& Aerospace Workers v. Fed. Election Comm'n, 678 F.2d 1092, 1117 (D.C. Cir. 1982).
} 
Union non-members are currently protected from being forced to fund union political expression or activity by opt-out rights under Abood v. Detroit Bd. of $E d ., 431$ U.S. 209 (1977), and plaintiff in this case seeks the more expansive right to refuse to fund any union activity whatsoever. In contrast, individual shareholders currently have no "opt out" rights or practical ability to avoid subsidizing corporate political expression with which they disagree. Nor do individuals have the practical option to refrain from putting any of their savings into equity investments, as doing so would impose damaging economic penalties and ignore conventional financial guidance for individual investors. If the Court decides to give union non-members additional rights to refuse to contribute to union speech, the Court should not act on the erroneous belief that this will accord union non-members the same rights enjoyed by individual investors.

Second, most Americans must routinely fund speech with which they disagree. While some of this compulsion is from practical reality rather than lawindividuals could in theory refuse to invest in any stocks or equity if they are willing to bear the potentially massive economic penalties that come from leaving their savings in cash and bonds-there are numerous examples outside the union context of laws that require individuals to fund expressive activities. This Court has dealt with public universities that require students to pay activities fees that fund groups those students may disagree with, $B d$. of Regents of Univ. of Wisconsin Sys. v. Southworth, 529 U.S. 217, 221 (2000), and state bars that use funds for regulating the legal profession, Keller $v$. State Bar of California, 496 U.S. 1, 13 (1990). Other examples abound, 
but most relevant here are the laws enacted by a number of states requiring public employees to contribute to defined contribution plans to fund their retirement. ${ }^{4}$ Michigan, for instance, requires many public employees to contribute at least $2 \%$ of their pay to a retirement plan, while Oklahoma requires at least $4.5 \% .{ }^{5}$ Not only do many of these plans require participants to pay fees to third-party administratorsentities that may use these funds for lobbying or other political activity-but as explained in this brief investment in virtually any retirement plan option requires subsidizing blatant political speech that the individual can neither affect nor prevent. There is, simply put, very little way for most individuals in modern America to avoid subsidizing speech with which they disagree.

Part I of this brief shows that corporate law does not afford shareholders any right to "opt out" or otherwise control the use of capital they have invested in a corporation. Part II explains that most corporate shareholders have no ability to use voting rights or sell their shares to prevent their invested capital from being used in ways with which they disagree. Part III

${ }^{4}$ Alicia H. Munnell et al., Defined Contribution Plans in the Public Sector: An Update, 37 State AND Local Pension Plans, April 2014, at 1, 2-4, available at http://crr.bc.edu/wp-content/ uploads/2014/04/SLP_37_508rev.pdf.

${ }^{5}$ Id. at 3; Oklahoma Public Employees Retirement System, The New Defined Contribution System: Understanding the Basics, http://www.opers.ok.gov/dc-basics (last visited Dec. 1, 2017). Ohio requires state teachers to contribute $14 \%$ of their pay to a defined contribution plan. STRS Ohio, DC Plan, https:// www.strsoh.org/aboutus/impact/dc.html (last visited Dec. 1, 2017). 
describes how investment structures, tax policy, and conventional financial advice all drive individuals to invest in ways that reinforce their inability to obtain information about or control corporate political spending.

\section{ARGUMENT}

\section{Individual Shareholders Generally Have No Right to "Opt Out" or Otherwise Control the Use of Capital They Invest in a Corporation.}

What can a shareholder do if she disagrees with a corporate expenditure, whether on a particular business strategy or in support of a political position? The short answer is very little. Shareholders do not typically have any right to control or direct the use of capital they have invested in a corporation, whether publicly or privately owned.

Authority over corporate funds resides in a board of directors and officers to whom the board delegates authority. ${ }^{6}$ Shareholders of U.S. corporations have no authority to instruct or control boards, officers, employees, or corporate agents in how they act for a cor-

${ }^{6}$ Robert Charles Clark, Corporate LaW 105 (Little, Brown \& Co., 1986) ("directors . . . have the formal legal power to manage the corporation"); Del. Code Ann. Title 8, §141(a) (West 2017). Delaware has been the leading corporate jurisdiction for decades, and this section is based primarily on Delaware law, but fairly summarizes the law in other states as well. 
poration, or to directly manage or act for a corporation. ${ }^{7}$ Instead, a "stockholder owns an interest in a share of stock, a financial investment granting no direct control over the properties, equipment, contract rights, organizational structure, and other elements that make up the corporation itself." 8

Indeed, a core goal of corporate law is to give directors and officers legal authority to act in ways with which shareholders may profoundly disagree. Directors, officers, employees, and corporate agents are not agents of shareholders, and owe shareholders no duty of obedience. ${ }^{9}$ This "separation of ownership and control" is often identified as a fundamental or essential attribute of the corporate form. ${ }^{10}$ "A review of elementary corporate law shows that [the] power of [a]

${ }^{7}$ CA, Inc. v. AFSCME Emps. Pension Plan, 953 A.2d 227, 232 (Del. 2008) ("it is well-established that stockholders of a corporation . . . may not directly manage the business and affairs of the corporation"). In Europe, shareholders do have rights to instruct directors. REINIER KRAAKMAN, ET AL., THE ANATOMY OF CORPORATE LAW 73 (Oxford 2d ed. 2009).

8 Martin Lipton \& Steven A. Rosenblum, A New System of Corporate Governance: The Quinquennial Election of Directors, 58 U. CHI. L. REV. 187, 193 (1991). For recent cases illustrating this point, see, e.g., Gorman v. Salamone, 2015 WL 4719681, *5 (Del. Ch. July 31, 2015); CA, Inc., 953 A.2d at 237.

9 Robert C. Clark, Agency Costs Versus Fiduciary Duties, in PRINCIPALS AND AGENTS: The STRUCTURE OF BUSINESS 55, 55-57 (John W. Pratt \& Richard J. Zeckhauser eds., Harvard Business School Press 1985).

10 E.g., Stephen M. Bainbridge, Corporation LaW AND EcONOMICS 8-9 (Foundation Press, 2002); WILLIAM T. ALLEN ET al., Commentaries and Cases on the LaW of Business ORGaNIZATION 79 (Aspen Publishers, 4th ed. 2012). 
principal to direct the activities of [an] agent does not apply to the stockholders against the directors or officers of their corporation."11

Directors and officers are fiduciaries for the corporation as a whole, and face judicial scrutiny in shareholder-initiated lawsuits over whether they have acted with care or engaged in self-dealing. ${ }^{12}$ However, their duties do not compel directors to use corporate funds to speak, or avoid speaking, in political controversies as they believe shareholders would prefer, because the most basic of corporate law doctrines-the "business judgment rule"-precludes judicial review of board decisions, absent evidence of a conflict of interest or a complete failure to exercise any care. ${ }^{13}$

${ }^{11}$ Clark, supra note 9 , at 56.

12 F.D.I.C. v. Wheat, 970 F.2d 124, 130 (5th Cir. 1992).

${ }^{13}$ Kamin v. Am. Express Co., 54 A.D.2d 654 (N.Y. App. Div. 1976), aff'g 338 N.Y.S.2d 807 (N.Y. Sup. Ct. 1976). The fact that corporate speech furthers a director's political views or goals would not typically give rise to a "conflict of interest" for corporate law purposes. Heightened judicial scrutiny generally requires a showing of financial "self-dealing" where a fiduciary "stands on both sides" of a transfer of assets to or from the corporation. Orman v. Cullman, 794 A.2d 5, 21-23 (Del. Ch. 2002) ("in the absence of self-dealing, it is not enough to establish the interest of a director by alleging that he received any benefit not equally shared by the stockholders"); Sullivan v. Hammer, 1990 WL 114223, *5-*6 (Del. Ch. Aug. 7, 1990), aff'd 594 A.2d 48 (Del. 1991) (corporate "gifts" merely required to be "within the range of reasonableness," and board decision can be overturned on selfdealing grounds "only if a plaintiff can show that a majority of the directors expected to derive personal financial benefit from the transaction"); see also Theodora Holding Corp. v. Henderson, 
Expenditures by corporations on politics do not typically generate heightened scrutiny, and shareholders cannot use derivative lawsuits to override decisions about such expenditures by boards. ${ }^{14}$ These facts about corporate law hold true even if (in an unrealistic hypothetical) shareholders were uniform in their political views, and uniformly opposed an expenditure approved by the corporate board. These facts are unquestionably true in a more typical situation where shareholders disagree among themselves about politics. Nor do shareholders have indirect

257 A.2d 398, 405 (Del. Ch. 1969); Sinclair Oil Corp. v. Levien, 280 A.2d 717, 721-22 (Del. 1971); Case v. N.Y. Cent. R.R. Co., 204 N.E.2d 643, 646-47 (N.Y. 1965); Shlensky v. Wrigley, 237 N.E.2d 776, 779 (Ill. App. Ct. 1968).

14 Victor Brudney, Business Corporations and Stockholders' Rights Under the First Amendment, 91 YALE L.J. 235, 257-58 (1981). The application of the deferential business judgment rule to political expenditures is so clear that few cases have even been pursued to a reported decision. A rare example, in which the court held the business judgment rule was a valid defense to an attack on a corporate contribution to a political action committee, is Finley v. Superior Court, 96 Cal. Rptr. 2d 128 (Cal. Ct. App. 2000). An exception that proves the rule is when political activity violates a statute, such as the statutory ban on corporate donations to a political party. A legal violation removes judicial deference under the business judgment rule. Miller v. Am. Tel. \& Tel. Co., 507 F.2d 759, 762 (3d Cir. 1974); cf. Barnes v. State Farm Mut. Auto. Ins. Co., 20 Cal. Rptr. 2d 87, 92-93 (Cal. Ct. App. 1993) (claim by policyholder of mutual insurance company seeking to stop insurer from engaging in political activities dismissed because decision was protected by business judgment rule and policyholder had no constitutional right to prevent insurer's use of premium revenues to support activities with which premium holder disagreed, nor to compel dividend to policyholders). 
means to accomplish this goal-such as selling shares or using votes-as explained next.

\section{Most Individual Shareholders Cannot In- directly Influence the Use of Their In- vested Capital for Political Expression.}

The basic corporate law set out in Part I is sometimes viewed as incomplete because, it is asserted, shareholders have indirect methods of achieving what corporate law bars them from achieving through $d i$ rect control. Shareholders, it is asserted or assumed, can "opt out" by withdrawing their funds if they do not approve of how directors are using their invested capital. ${ }^{15}$ Alternatively, they can use their power to vote to elect directors who will act as shareholders want. 16

These assumptions are wrong for most shareholders. Controlling shareholders ${ }^{17}$ may be able to control directors, but most shareholders beneficially own stock as minority investors in corporations with dispersed ownership. Most investors have little influence, direct or indirect, on a typical corporate board. As stated by the Chief Justice of the Delaware Supreme Court, "the practical realities of stock market ownership have changed in ways that deprive most

15 E.g., Bellotti, 435 U.S. at 794 n.34 (a "shareholder invests in a corporation of his own volition and is free to withdraw his investment at any time and for any reason.”).

${ }^{16}$ E.g., id. at 794-95 (emphasizing shareholders' "power to elect the board of directors" as a way "to protect their own interests.").

17 "Controlling shareholder" means a shareholder with sufficient shares to determine the outcome of director elections. 
stockholders of both their right to voice and their right of exit."18 Both the right to sell and the right to vote are typically useless for shareholders as a means of controlling or influencing specific corporate actions, including the use of corporate funds for political purposes.

\section{A. Shareholders do not typically have the right to compel a corporation to repurchase or find a buyer for their shares.}

Shareholders may not withdraw any of the funds they have invested in a corporation except insofar as a majority of the board approves a dividend or stock repurchase. ${ }^{19}$ Shareholders who wish to sell shares can only do so by finding third party buyers on their own. But finding a buyer is typically difficult if not impossible at the majority of corporations, as discussed next.

B. Shares of most corporations are not traded on public markets, and finding buyers for such shares is difficult or impossible.

More than six million corporations file U.S. income

${ }^{18}$ Leo E. Strine, Jr. \& Nicholas Walter, Conservative Collision Course?: The Tension Between Conservative Corporate Law Theory and Citizens United, 100 CoRNELL L. REV. 335, 370 (2015).

19 See Del. Code Ann. Title 8, § 151(b) (West 2017) (every Delaware corporation must have at least one class of non-redeemable common stock); Blaustein v. Lord Baltmore Capital Corp., 84 A.3d 954, 958-59 (Del. 2014); Nixon v. Blackwell, 626 A.2d 1366, 1379-80 (Del. 1993). 
tax returns. 20 Only about 4,000 corporations are listed on a U.S. stock exchange-less than $0.1 \%$ of corporations that filed tax returns. ${ }^{21}$ Of the rest, some are owned by a single shareholder, but many are beneficially owned by dispersed minority owners. Most publicly traded companies are bigger, on average, than companies that lack active public markets for their shares. But many companies without public markets are still large and have substantial numbers of shareholders. Examples include Cargill, with revenues exceeding $\$ 130$ billion and over 200 shareholders, and Mars, with revenues exceeding $\$ 33$ billion and over 45 shareholders. ${ }^{22}$ Large non-listed companies also include those controlled by private equity

20 INTERNAL REVENUE SERVICE, 2016 StATISTICS OF INCOME, 2016 TAX STATisTiCs 2 (2016), available at https://www.irs.gov/ pub/irs-soi/16taxstatscard.pdf (including S corporations).

${ }^{21}$ Listed Domestic Companies, Total, THE WoRLD BANK, http://data.worldbank.org/indicator/CM.MKT.LDOM.NO (last visited Dec. 1, 2017). More corporations are registered with the Securities and Exchange Commission (SEC), OFFICE OF ECONOMIC ANALYSIS, SECURITIES AND EXCHANGE COMMISSION, STUDY OF SARBANES-OXLEY ACT OF 2002 SECTION 404 INTERNAL CONTROL OVER FINANCIAL REPORTING REQUIREMENTS 21 (Sept. 2009), available at http://www.sec.gov/news/studies/2009/sox404_study.pdf, but many do so because they have publicly traded bonds and few shareholders, or lack significant amounts of trading volume. John C. Coates IV, The Powerful and Pervasive Effects of Ownership on $M \& A$ (June 2010), at 5, available at http:// ssrn.com/abstract=1884157 (Table 1).

22 Andrea Murphy, America's Largest Private Companies 2014, ForBES (Nov. 5, 2014), available at http://www.forbes.com/ sites/andreamurphy/2014/11/05/americas-largest-private-companies-2014/; see also Petro Lisowsky \& Michael Minnis, Accounting Choices and Capital Allocation: Evidence from Large Private U.S. Firms (Dec. 2016 working paper), at 16-18 \& Table 
funds, which represent dispersed investors through a variety of intermediaries. ${ }^{23}$ In total, the value of unlisted corporations represents one-third to one-half of the value of all U.S. corporations. ${ }^{24}$

Listed shares trade in significant volume-thousands of shares per day. By contrast, shares of the vast majority of corporations do not trade in public markets at all. When they do trade, they do so only erratically. ${ }^{25}$ Finding a buyer for shares that are not

3, available at http://ssrn.com/abstract=2373498 (analyzing data on number of private firms and the ownership of those private firms); Christian Leuz et al., Why Do Firms Go Dark? Causes and Economic Consequences of Voluntary SEC Deregistrations, 45 J. ACCOUNT. ECON. 181, 181 (2008) (hundreds of corporations are no longer registered with the SEC but continue to have numerous shareholders).

${ }^{23}$ Private equity funds invested $\$ 644$ billion in U.S.-based companies in 2016. Private Equity: Top States \& Districts, AMERICAN INVESTMENT COUNCIL, http://www.investmentcouncil.org/private-equity-at-work/education/private-equity-topstates-districts/ (last visited Dec. 1, 2017).

24 John C. Coates IV, Thirty Years of Evolution in the Roles of Institutional Investors in Corporate Governance, in RESEARCH HANDBOOK ON SHAREHOLDER POWER 79, 89 (Jennifer G. Hill \& Randall S. Thomas eds., Edward Elgar 2015) (Table 4.1). SEC rules require registration by companies with more than 500 unaccredited record shareholders (or more than 2000 accredited investors) and $\$ 10$ million or more in assets. 15 U.S.C.A. $\S \S 78 l$, $78 \mathrm{~m}, 78 \mathrm{o}$ (d) (West 2017). Public company shareholders are also unable to use sales or votes to influence political spending, for reasons discussed below.

25 Leuz et al., supra note 22 , at 184, 204-05 (reporting on private companies with stocks that are traded but only at low levels, with trading not occurring on many days). Private equity 
traded on public markets is difficult, and sometimes impossible, at least at any reasonable price.

Shares of unlisted corporations trade at heavily discounted prices relative to their intrinsic value because of their lack of liquidity. ${ }^{26}$ One study found that, controlling for observable differences unrelated to liquidity, stocks increased in price by $25 \%$ when first listed on the New York Stock Exchange. ${ }^{27}$ Similarly, a study showed that prices for companies without publicly traded stock can be $30 \%$ lower than for comparable publicly held companies. ${ }^{28}$ A minority equity position does not have ability to control the decisions of the company, resulting in a further decrease in value known as a "minority discount." 29 Even if shareholders are willing to accept such discounts,

funds do not trade stocks, except as part of a sale of an entire corporation, as chosen by fund advisors, not fund investors.

${ }^{26}$ Reasons for this include: Few buyers have information about such companies or sellers. Few sellers have information about potential buyers, or even who they may be. Few dealers hold such shares in inventory, and few brokers are available to look for buyers. Few if any research analysts cover such companies. Transaction costs will be significant relative to the sale. Such shares are held longer, tax bases are lower, and sales trigger higher taxes. Fraud risk is higher, as such companies are not subject to disclosure laws or SEC enforcement.

27 Gary C. Sanger \& John J. McConnell, Stock Exchange Listings, Firm Value, and Security Market Efficiency: The Impact of NASDAQ, 21 J. Fin. QUANT. ANAL. 1, 14, 16 (1986).

28 John Koeplin et al., The Private Company Discount, 12 J. APPL. CORP. Fin. 94, 95 (2000).

${ }^{29}$ John C. Coates IV, "Fair Value" as an Avoidable Rule of Corporate Law: Minority Discounts in Conflict Transactions, 147 U. PA. L. REV. 1251, 1262-63 (1999). 
sales of stock of private companies take significant time and trigger taxes, reducing the attractiveness of "exit" in response to corporate actions the shareholder disfavors.

In sum, the majority of individual owners of shares of the majority of corporations would incur significant economic costs to sell their shares.

\section{Stock sales cannot generally be used to prevent, deter, or influence the political activities of publicly traded companies.}

Even for shareholders of publicly listed companies, the ability to sell is generally not an effective remedy for undesirable corporate political expenditures. Disclosure laws are currently such that shareholders do not receive information that would enable sales in advance of, or even in response to, political expenditures. From the perspective of the shareholder, a sale in response to an unwanted political expenditure would come too late, would be at a price where the expenditure was already "priced in," and would entail relatively large costs (including taxes). As such, individual share sales would at best be the equivalent of closing the barn door after a horse has been stolen, the stock being sold at a price that already reflects the conduct to which the shareholder objected.

Federal law does not require corporations to provide shareholders with advance notice of political expenditures. ${ }^{30}$ In fact, most public companies do not disclose anything about political expenditures, even

${ }^{30}$ Lucian A. Bebchuk \& Robert J. Jackson, Jr., Corporate Political Speech: Who Decides?, 124 HARV. L. REV. 83, 89 (2010). 
after the fact, except for contributions to connected political action committees that are required to be disclosed under lobbying disclosure laws. Efforts to petition the SEC to adopt disclosure requirements for public companies ${ }^{31}$ have to date been unavailing, and lobbying regulations are underenforced and far from comprehensive. ${ }^{32}$ While an increasing number of the very largest companies have voluntarily adopted disclosure policies, few make comprehensive disclosures - they do not, for example, report their contributions to trade groups that lobby on their behalf. ${ }^{33}$ Almost none makes these disclosures in advance. ${ }^{34}$

A prominent set of undisclosed corporate expenditures are dues and other contributions to trade groups or organizations organized under Internal Revenue

31 See Committee on Disclosure of Corporate Political SPENDING, PETITION FOR RULEMAKING (Aug. 3, 2011), available at http://sec.gov/rules/petitions/2011/petn4-637.pdf.

32 Charles Fried et al., Lobbying Law in the Spotlight: Challenges and Proposed Improvements, 63 ADMIN. L. REV. 419, 43436, 462-63 (2011).

33 See Zicklin CEnTer for Business Ethics Research at the Wharton School of the Univ. of Pennsylvania, The 2015 CPA-ZiCKLIN INDEX OF CORPORATE POLITICAL Disclosure AND ACCOUNTABILITY 14-15 (Center for Political Accountability 2015), available at http://tinyurl.com/out9bfj. Shareholders can seek information about political spending based on their rights to inspect corporate "books and records," e.g., Del. Code Ann. Title $8, \S 220$, but to be effective such requests typically require threatened or actual litigation and resources beyond those available to most shareholders.

${ }^{34}$ ZICKLIN, supra note 33, at 14-15. 
Code subsections 501(c)(4) and 501(c)(6). ${ }^{35}$ Those organizations can spend up to half of their revenues on politics without being treated as "political" by the Internal Revenue Service and without disclosing specific donors, and they may be able to spend more, to the extent tax law is underenforced. Occasional leaks or accidental disclosures reveal that many public corporations give substantial sums to these organizations. ${ }^{36}$ Outside such accidental disclosures, shareholders ordinarily never learn about these expenditures even after the fact, much less in advance.

Shareholders thus have no means to respond to corporate political spending to which they object. Shareholders often never find out their money is being used to fund political expression or activity to which they would object, and even when they do find out, any sale of shares will be too late to allow them to "opt out" of that spending. By the time the sale occurs, the political speech has already been made in the name of the corporation with the shareholders' money. Without comprehensive disclosure, even the deterrent effect of after-the-fact sales has little force.

In addition, given that "market professionals generally consider most publicly announced material

${ }^{35}$ For data on spending by such organizations, see Bebchuk \& Jackson, supra note 30, at 94 .

${ }^{36}$ E.g., Jonathan Weisman, G.O.P. Error Reveals Donors and the Price of Access, N.Y. TIMES, Sept. 24, 2014, at A15, available at http://www.nytimes.com/2014/09/25/us/republicans-corporate-donors-governors.html?_r=0 (article detailing inadvertent disclosures of members of 501(c)(4), including Coca-Cola, Exxon Mobil, Pfizer, and Walmart, each of which contributed at least $\$ 250,000)$. 
statements about companies, thereby affecting stock market prices," 37 any expenditure will have already had whatever effect on share value it is likely to have by the time a shareholder learns about it, and any sale by the shareholder will be at a price reflecting that effect. Sales of shares would also generate transaction costs and trigger taxes. As a result, they would only occur if a shareholder were willing to incur material economic losses to protest the use of the shareholder's invested capital.

From the perspective of a corporate board, if shareholders sold shares en masse to protest the same political expenditure, and buyers of the stock shared the same negative view of the expenditure, the company's stock price could fall, increasing its cost of capital. However, shareholders have no way to coordinate among themselves in choosing whether or when to sell. They are also unlikely to respond uniformly or rapidly to the limited information available about political expenditures, in part because they (and potential buyers of the stock) disagree about politics and the importance of any given expenditure.

Even if shareholders could overcome their collective action problem, even if they had uniform views about politics, and even if potential buyers of their stock shared their views, companies raise relatively little capital from equity investors after their initial

${ }^{37}$ Halliburton Co. v. Erica P. John Fund, Inc., 134 S.Ct. 2398, 2403 (2014) (quoting Basic Inc. v. Levinson, 485 U.S. 224, 248, n.28 (1988)). 
public offerings. ${ }^{38}$ They instead rely on earnings and external debt to fund growth. ${ }^{39}$ The prospect of slightly higher equity capital costs due to sales by shareholders would not deter most corporations from political activity.

In sum, shareholders cannot control or deter political expenditures by selling their stock, or threatening to do so, even at public companies. This is true even though many individual shareholders may in fact disapprove of corporate political speech. The majority of the beneficial owners of public companies have no practical way to withdraw their capital to prevent or control corporate political expenditures.

\section{Shareholder voting rights are not generally useful for directing or influencing specific corporate actions.}

The right to vote is no more useful than the right to sell for shareholders who wish to control corporate political expenditures. The reason is simple: Most shareholders-and the majority of individual shareholders in public corporations-are not controlling shareholders. ${ }^{40}$ That is, they do not have sufficient

38 Jonathan Berk \& Peter DeMarzo, Corporate Finance 524-25 (Pearson, 3d ed. 2014).

${ }^{39} \mathrm{Id}$.

40 See note 15 above. A listed company will have in excess of 500 shareholders on the company's stock ledger ("record" shareholders), and in fact public companies have on average more than 12,000 record shareholders. Coates, supra note 21 , at 5 (Table 1). Some companies, such as Procter \& Gamble, have more than 2,000,000 shareholders. Id. at 5. By definition, only 
voting rights to control their companies, nor do they have the capacity to acquire control of the companies in which they invest. Their voting rights give them no practical ability to influence management generally, much less to control or opt out of specific political expenditures.

The majority of corporations with dispersed ownership have one of two types of ownership structures, neither of which creates practical opportunities for voting rights to influence board decisions. At many corporations, one person or small group has a control "block" with effective ability to control the election of

one shareholder can be a "majority shareholder" for any company. Even if several shareholders together control the company, the number of shareholders in the control group will usually be no more than a few.

An average public company thus has 12,000 minority shareholders and only one majority shareholder or a few control shareholders. Even this understates the ratio of minority to control shareholders, because (as discussed in Part III) two-thirds of record shareholders are institutions, which invest on behalf of thousands (or in aggregate, millions) of others. Marshall E. Blume \& Donald B. Keim, The Changing Nature of Institutional Stock Investing (Nov. 12, 2014 working paper), at 2-3, available at http:// tinyurl.com/qhqskrp; Coates, supra note 24, at 81 . More than 95 million individuals own shares through 3,200 U.S. domestic equity mutual funds, for example. Kimberly Burham et al., Ownership of Mutual Funds, Shareholder Sentiment, and Use of the Internet, 2013, ICI RES. PERSP., Oct. 2013, at 1, available at https://www.ici.org/pdf/per19-09.pdf; BRIAN REID ET AL., 2015 INVESTMENT COMPANY FACT BOOK 177 (Investment Company Institute, 5th ed. 2015) available at http://www.ici.org/pdf/ 2015_factbook.pdf (Table 5). Thus, the true ratio of minority to control shareholders is vastly higher than 12,000 to 2 or 3 that the record shareholder data suggest. 
directors, which renders the nominal voting rights of minority investors incapable of changing the composition of the board. ${ }^{41}$ Examples include Walmart, Ford, Google, and Facebook. A recent study found that $96 \%$ of a representative sample of U.S. companies listed on a stock exchange have a voting block with $40 \%$ of the stock on average, and in many the block controls a majority of shares. ${ }^{42}$ Since directors are elected based on a plurality or majority of shares voted, an effort by a minority shareholder seeking to displace a director at these companies is either wholly futile (where a majority block will determine the outcome), or would require convincing more than $95 \%$ of non-affiliated shareholders, a burden that is insurmountable in practice.

In the second category, most public companies that lack majority or near-majority blockholders are large and have such dispersed ownership that few if any shareholders are capable of overcoming the costs of coordinating other shareholders to mount an effective election contest. ${ }^{43}$ To elect directors at public companies, shareholders must solicit "proxies," which requires significant legal and communication costs. Incumbent directors, by contrast, can rely on corporate funds to pay their costs of fighting the contest. A

${ }^{41}$ Clifford G. Holderness, The Myth of Diffuse Ownership in the United States, 22 REV. FIN. STUD. 1377, 1378-80 (2009).

${ }^{42} I d$. at 1382 .

${ }^{43}$ KRAAKMAN ET AL., supra note 7, at 29, 62. 
proxy contest typically lasts months ${ }^{44}$ and is "extraordinarily expensive" for shareholders, ${ }^{45}$ who commonly incur more than ten million dollars in expenses ${ }^{46}$ and are still outspent by incumbents. ${ }^{47}$ Even when pursued by well-resourced activist hedge funds, proxy contests are often unsuccessful. ${ }^{48}$ To give their proxy fights a boost, hedge funds build blocks of stock that are substantially larger than most individuals own or could afford-yet even hedge funds generally avoid full-blown proxy contests. ${ }^{49}$ While activist hedge funds have been increasing in influence and activity levels over time, their resources well exceed those of most individuals. Institutions that invest on behalf of

44 Nickolay Gantchev, The Costs of Shareholder Activism: Evidence from a Sequential Decision Model, 107 J. Fin. ECON. 610, 621 (2013) (Table 4).

45 Jana Master Fund, Ltd. v. CNET Networks, Inc., 954 A.2d 335, 341 (Del. Ch. 2008) (citing RANDALl S. THOMAS \& CATHERINE T. DIXON, ARANOW \& EISHORN ON PROXY CONTESTS For CORPORATE CONTROL $§ 21.01$ (3d ed. 2001 supp.)).

${ }^{46}$ Gantchev, supra note 44, at 610.

${ }^{47}$ Mark A. Stach, An Overview of Legal and Tactical Considerations in Proxy Contests: The Primary Means of Effecting Fundamental Corporate Change in the 1990s, 13 Geo. Mason U. L. Rev. 745, 776 (1991).

${ }^{48}$ Gantchev, supra note 44, at 620 .

${ }^{49} \mathrm{Id}$. at 618 (Gantchev assembles a comprehensive data set of proxy contests between 2000 and 2007 and identifies only 74 that qualify-less than $0.1 \%$ of all elections of corporate directors over that period). A more recent study finds a modest increase in 2008 and 2009, but then a fall-off in 2010, and in all years proxy contests occur in only a tiny fraction of board elections. Vyacheslav Fos \& Margarita Tsoutsoura, Shareholder Democracy in Play: Career Consequences of Proxy Contests, 114 J. FIN. ECON. 316, 339 (2014) (Fig A1). 
most individuals - such as mutual funds and pension funds-rarely wage proxy contests.

In sum, whether because of insider blocks, or because of the collective action costs of proxy contests, most shareholders of U.S. public companies do not have meaningful ability to use their votes to influence boards of directors about anything, much less specific political expenditures.

\section{Many Individuals Are Effectively}

Compelled to Maintain Investments in Companies Whose Political Expenditures They Do Not Know and Cannot Control.

The bottom line of Part II is that the majority of individual shareholders cannot use their rights to sell or vote to avoid subsidizing corporate political speech

or activity with which they disagree. Reinforcing these limits are three trends in the ownership of U.S. corporations over the last thirty years. These trends are towards (1) more institutional ownership, (2) more "layers" of institutions between individual owners and corporations, and (3) a general weakening of the ability of individuals to take action-whether through sales, votes, lawsuits, or otherwise-to respond to corporate activities.

A partial cause of these trends is the now-standard financial advice for individuals to invest in diversified, low-cost, broad-based baskets of stocks and to "buy and hold" for the long term. Standard employersponsored retirement savings plans-a channel through which an increasing share of investment flows-make it difficult or impossible for individuals to do otherwise. Institutional intermediaries are not 
generally required to pass along to individual investors information they may receive as record (i.e., formal) shareholders about specific decisions by corporations they own. Together, these forces effectively cause an increasing number of individuals to maintain investments in corporations, even if the individuals disagree with political speech by corporations using their investment capital.

\section{A. Most beneficial owners of public corporations are individuals who own through institutions such as mutual funds and pension funds.}

Since the mid-20 th century, institutions-pension funds, insurance companies, bank trusts, mutual funds, and other intermediaries-have held increasing amounts of stock issued by American corporations. Figure 1 reflects the Federal Reserve's "Flow of Funds" data, a standard source of information about this trend. ${ }^{50}$ The Fed's data make clear the general magnitude and persistence of the trend toward institutional ownership.

50 BOARD OF GOVERNORS OF THE FEDERAL RESERVE System, FinANCIAL ACCOUNTS of THE United States: Flow of Funds, BALANCE SHEETS, AND INTEGRATED MACROECONOMIC ACCOUNTS 118 (2017), available at http://www.federalreserve.gov/releases/ z1/current/z1.pdf (Table L.223). These data are not comprehensive, and understate institutional ownership because they count private equity funds, non-profits, and hedge funds in the "household" sector. Coates, supra note 24, at 89. 
26

Figure 1: Institutional Ownership of U.S. Corporate Equity

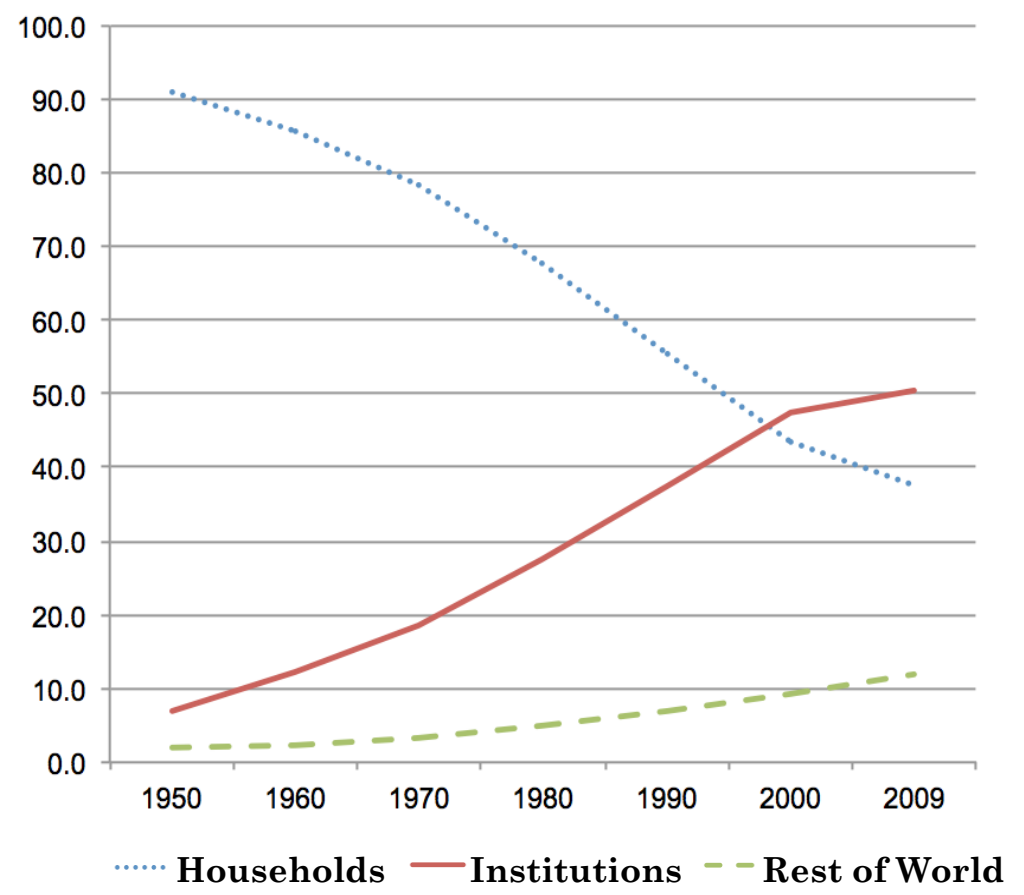

The increase in institutional ownership began as early as the 1950s, and has continued steadily ever since. While ownership by the types of "institutions" the Fed tracks leveled off after 2000, other institutions, such as hedge funds and private equity funds, have continued to increase their ownership. The result is that less than one-third of total equity in U.S. companies is now held directly by individuals.

The number of institutional layers between any given corporation and the individuals who indirectly own its stock (the "beneficial owners") has also grown. Institutions own about $10 \%$ of stock held by equity mutual funds, and a larger share of other mutual funds-an increasing trend of individuals owning 
shares of institutions, which in turn invest in other institutions, which in turn own corporate stock. ${ }^{51}$

Mutual funds are a good example. Corporate law only allows formal "record" owners that have held shares continuously or on a certain date to exercise shareholder rights. ${ }^{52}$ Mutual fund shares are commonly owned in "omnibus accounts" in which a broker pools shares on behalf of multiple clients in "sub-accounts," commonly including pension funds or insurers, some of which invest on behalf of multiple beneficiaries. ${ }^{53}$ This pooling and commingling means that individuals who invest their savings in mutual funds - or who were forced to put their workplace retirement savings into mutual funds-are not the formal owners of "record" of any of the companies their savings are supporting.

51 REID ET AL., supra note 40, at 217 (funds of funds), 234 (institutional investors other than funds of funds) (Tables 45, 62).

52 In re Appraisal of Dell Inc., 2015 WL 4313206, *3 (Del. Ch. July 13, 2015) (granting motion for summary judgment, holding institutional investors did not have appraisal rights because administrative transfers among the layers of ownership violated what the court acknowledged was a technical and antiquated system focusing on continuous formal record ownership).

53 OFFICE OF COMPLIANCE InSPECTIONS AND EXAMINATIONS, SECURITIEs AND Exchange Commission, NATional ExAM RisK ALERT 1, 4 (Sept. 29, 2011), available at http://www.sec.gov/ about/offices/ocie/riskalert-mastersubaccounts.pdf. 


\section{B. Individuals who own stock through intermediaries do not have the right to direct the sale or votes of their shares.}

Most corporate stock held by institutions are held by separate legal entities, such as mutual funds, pension funds, insurance companies, hedge funds, and private equity funds. Such entities do not pass through to their own beneficial owners either the rights to vote or sell the shares of the stock they purchase. Pension fund beneficiaries, for example, have no ability to influence the companies in which the funds are invested. ${ }^{54}$ Insureds have no ability to control how insurance companies invest the premiums they pay. Investors in mutual funds or exchangetraded funds do have the ability to select funds based on stated investment policies, just as annuitants generally have the ability to set basic investment parameters for how their funds are invested; once their funds are invested, however, the annuitants and fund investors have no ability to force the divestment of a particular corporate stock, and may only divest from the fund as a whole. Even the professional managers of the increasingly important category of index funds cannot sell a given company's stock, because they have precommitted to hold an entire index.

Individuals who own any of these types of institutional investments cannot exercise voting rights associated with the shares. Instead, those rights are exercised by the management of the institutions. Individuals that invest through institutions face collective

\footnotetext{
54 Adam Winkler, Beyond Bellotti, 32 Loy. L.A. L. REV. 133,
} 167 (1998). 
action problems that are just as large as (if not larger than) those facing individuals who directly invest in corporations. The result is that most individuals, who now primarily invest through separate entity intermediaries, cannot even exercise the limited powers analyzed in Part II.

To make these points concrete, consider an individual who buys the stock of a large broad-based stock fund, such as Vanguard's S\&P 500 index fund. That individual's savings are invested in the stocks of companies listed on the S\&P index. Currently, that fund owns shares of Apple, Inc. If, hypothetically, Apple's board or its government affairs officer were to spend money on political speech disfavored by the individual, the individual has no power to compel Vanguard to sell Apple stock in response. Nor can the individual compel Vanguard to vote against Apple's current directors. All the individual can do is to sell the Vanguard fund shares. But if the individual wants to invest in a broad-based large-cap fund of any kind, which would be advisable for reasons discussed next, that individual would only be selling Vanguard shares to buy another fund's shares, which in turn would be likely to own Apple stock. In short, unless an individual decides to ignore standard financial advice about how to invest, there is no way to avoid an investment in Apple, however disagreeable its political activities may be.

\section{Individual investors have little prudent choice other than investing through institutions to achieve diversification.}

Part of the reason for the growth in institutional 
investors is that finance theory and conventional financial advice long ago identified the fact that most individuals are not well situated to select specific stocks from thousands of equity investments. ${ }^{55}$ Standard financial theory also has long identified diversification as an important tool for investors to achieve the best risk-adjusted returns. ${ }^{56}$

Diversification entails identifying and maintaining a substantial number of investments, not just one or a few, and monitoring the companies selected over time. For example, when two companies merge, when one company goes bankrupt, or when a company divests a major business, investors must "rebalance" their portfolios to maintain a desired degree of diversification and risk. Dividends must be reinvested, brokers retained, tax records kept, and filings made. Maintaining a diversified portfolio requires effort, expertise, and time.

Professional asset management has also increasingly been most cost-effective for individual investors through passive, indexed investment strategies. ${ }^{57}$

${ }^{55}$ For an empirical study documenting the disadvantages individual direct investors face, see Brad M. Barber \& Terrance Odean, Trading Is Hazardous to Your Wealth: The Common Stock Investment Performance of Individual Investors, 55 J. FIN. 773 (2000).

${ }^{56}$ Harry M. Markowitz, Portfolio Selection, 7 J. Fin. 77, 79 (1952).

57 Burton G. Malkiel, Returns from Investing in Equity Mutual Funds 1971 to 1991, 50 J. FIN. 549, 571 (1995); RICHARD A. Posner, ECONOMIC ANALYSIS OF LAW 596 (Aspen Publishers, 8th ed. 2011). 
Such strategies involve buying and holding broadbased index funds or financial products that mimic such funds, which can achieve hard-to-beat returns at low cost over sustained periods of time. Most nominally "active" mutual funds rely to a large extent on passive investment in baskets of stock, and simply "overweight" or "underweight" portions of the relevant market benchmark. ${ }^{58}$ Pension funds, too, outsource portfolio management to advisers that invest in large numbers of public companies, rather than a select few.

A further force leading individuals to invest through institutions is the growing use of defined contribution (DC) retirement plans such as $401(\mathrm{k})$ and 403(b) plans. ${ }^{59}$ As noted above, some states require public employees to invest in DC plans, ${ }^{60}$ and in the private sector those plans may be effectively compelled as well. Investment through DC plans enjoys strong tax benefits ${ }^{61}$ or, equivalently, investors pay

58 K.J. Martijn Cremers \& Antti Petajisto, How Active Is Your Fund Manager? A New Measure That Predicts Performance, 22 REV. FIN. STUD. 3329, 3330 (2009).

59 "Defined contribution" plans do not promise specific benefits, but instead allocate specific amounts as elected by an employee from their wages (sometimes matched by the employer) into an investment account to be held for the employee's benefit, typically until retirement. In contrast, more conventional pension plans are called "defined benefit" plans because they promise beneficiaries a specific set of benefits in retirement, and the risk of investment shortfalls is borne by the plan sponsor.

60 See supra pp. 5-6 \& nn. 4-5.

${ }^{61}$ Retirement Savings Contributions Credit (Saver's Credit), INTERNAL REVENUE SERVICE, https://www.irs.gov/Retirement- 
economic penalties to invest outside a plan. As a result, "[v]irtually all saving by the working-age population currently takes place within employer-sponsored pension plans." 62 An annual survey of employer-sponsored plans found that $78 \%$ of eligible employees participate, and fully diversified plan options are the default and most common investment choice. ${ }^{63}$ Less than 10\% of DC plans gave employees the option to directly manage their investments in individual stocks, and even those impose additional fees on investors. ${ }^{64}$

While employees are given choices within DC plans, these plans are designed by employers with little input from typical employees. Most plans impose significant limits on the flexibility of employee-investors to choose from the universe of potential investments, and commonly direct investments into the kind of diversified index or other broad-based funds that standard finance theory and advice recommends

Plans/Plan-Participant,-Employee/Retirement-Savings-Contributions-Savers-Credit (last updated Oct. 26, 2017) ("The amount of the [tax] credit is $50 \%, 20 \%$ or $10 \%$ of your retirement plan or IRA contributions up to $\$ 2,000$ ( $\$ 4,000$ if married filing jointly), depending on your adjusted gross income ....”).

62 Alicia H. Munnell et al., What's the Tax Advantage of 401(k)s?, CENTER FOR RETIREMENT RESEARCH AT BOSTON COLLEGE, Feb. 2012, at 6, available at http://tinyurl.com/ndjkdwh.

${ }^{63}$ AON HewitT, 2014 Universe Benchmarks Highlights 1, 4 (2014), available at http://tinyurl.com/n964gmq.

${ }^{64}$ Ian Ayres \& Quinn Curtis, Beyond Diversification, 124 YALE L.J. 1476, 1485 \& n.28, 1539 (2015). 
for individuals. ${ }^{65}$ An individual might get to select between an international index fund and an S\&P 500 fund, but would rarely get to select between investing in Apple and Walmart.

"The most common type of investment options in 401(k) plans are mutual funds or similar investment vehicles that pool funds managed by a professional fund manager."66 Early withdrawals from these accounts are tax penalized 67 and discouraged by plan design. 68 Similar tax subsidies and restrictions apply to 529 plans, which have been increasingly used by

\footnotetext{
65 Anne Tucker, Flawed Assumptions: A Corporate Law Analysis of Free Speech and Corporate Personhood in Citizens United, 61 CASE W. RES. L. REV. 497, 539 (2010); see also Anne Tucker, Retirement Revolution: Unmitigated Risks in the Defined Contribution Society, 51 Hous. L. REV. 153, 181-82 (2013); BRIGHTSCOPE \& INVESTMENT COMPANY INSTITUTE, THE BrightScope / ICI Defined Contribution Plan Profile: A Close LoOK AT 401(K) Plans 7, 15-17, 25 (2014), available at http://www.ici.org/pdf/ppr_14_dcplan_profile_401k.pdf (documenting number of investment options, portion in types of asset classes, growth in indexed equity funds within DC plans, and that about $80 \%$ of plan assets are invested in diversified institutions).

${ }^{66}$ Ayres \& Curtis, supra note 64, at 1485, citing Sarah Holden et al., 401(k) Plan Asset Allocation, Account Balances, and Loan Activity in 2012, 19 ICI RES. PERSP. Dec. 2013 at 1, 21.

${ }^{67}$ I.R.C. § 401(k) (West 2017).

68 Phil Edwards et al., Defined Contribution Plan Success Factors, DCIIA, May 2015, at 4, available at https://tinyurl.com/ yd9vgfmt.
} 
individuals to save for college education for their children. ${ }^{69}$ To benefit from the tax subsidies fueling the growth in DC plans, individuals must give up the right to choose or influence the corporations in which they invest.

As a result of these trends in financial management, it is difficult for most individual investors to find any means of investing in corporate stock that does not rely on both institutional intermediaries and a broad-based, index or quasi-index strategy for investing. The bottom line is that most individuals now invest in a large number of public companies, but do so indirectly, and generally cannot pick and choose stocks based on the recent or expected specific behavior of corporate issuers. This is true for public employees in many states, and private employees across the nation.

\section{Institutional intermediaries are not generally required to track or disclose to their beneficiaries the political activities of the companies in which they invest.}

Another effect of increased institutional ownership of corporate stock, and of increased "layers" of institutions, is to decrease further the amount of information that a typical individual shareholder can obtain about the political activities of the companies in which the individual invests. As discussed above,

69 See An Introduction to 529 Plans, SeCURITIES AND EXCHANGE COMMISSION, http://www.sec.gov/investor/pubs/intro 529.htm (last modified Jan. 6, 2014) ("participants in college savings plans have limited investment options and are not permitted to switch freely among available investment options.”). 
most corporations do not provide detailed information about political expenditures. What limited information they do provide to shareholders is given to shareholders of record, which are increasingly institutional investors.

Institutions, in turn, report the values of their investments, but they are not required to gather, analyze, and pass on information about the activities of the companies in their portfolio. Institutions such as mutual funds do not typically report to their investors even basic financial information about companies in which they invest, such as earnings, much less operational information such as political expenditures. Nor do institutions typically devote any effort to monitor political activities of the companies in which they invest. Thus, even if individuals wanted to pressure the companies they indirectly own to alter political expenditures, they would lack even the most basic rights to obtain information to know where to focus their pressure.

E. Most individual investors are in practice compelled to maintain investments in companies that can engage in political expenditures with which the investors disagree.

Together, the forces described in this Part III effectively compel an increasing number of individuals to maintain investments in large numbers of corporations, even if the individuals disagree with political expressions or activities taken by those corporations. 
Individuals of course can choose not to invest in stock at all, or choose not to invest in stock through retirement plans. But avoiding all equity investment imposes a massive economic penalty over time. ${ }^{70}$ Using conventional figures for expected returns on diversified equity investments and contrasting them with investments in Treasury bonds, Figure 2 depicts how large the economic penalty of staying out of stocks altogether grows over the course of a typical investor's life. ${ }^{71}$

The results are dramatic. An investor in stocks can expect to have more than eight times as much money after 35 years as an investor making the same investment in government bonds. There simply is no economic "option" for ordinary individuals saving for retirement to choose to avoid stocks altogether.

${ }^{70}$ Benjamin I. Sachs, Unions, Corporations, and Political Opt-Out Rights After Citizens United, 112 ColuM. L. REV. 800, 838-40 (2012).

71 The figure uses data from Aswath Damodaran, Annual Returns on Stock, T.Bonds and T.Bills: 1928-Current, http:// pages.stern.nyu.edu/ adamodar/New_Home_Page/datafile/ histretSP.html (last updated Jan. 5, 2017). It assumes a fixed one-time investment of $\$ 1,000$ by an investor at age 30 , and compounds returns annually on a diversified portfolio of equity investments using an expected rate of return composed of the Treasury bond rate of $2.22 \%$ and an implied equity risk premium of $6.28 \%$, derived from trailing twelve-month cash yield on investments in the $S \& P 500$. It compares the return on that investment with the return on investment on Treasury bonds over the same period. 
Figure 2: The Cost of Opting Out of Stock

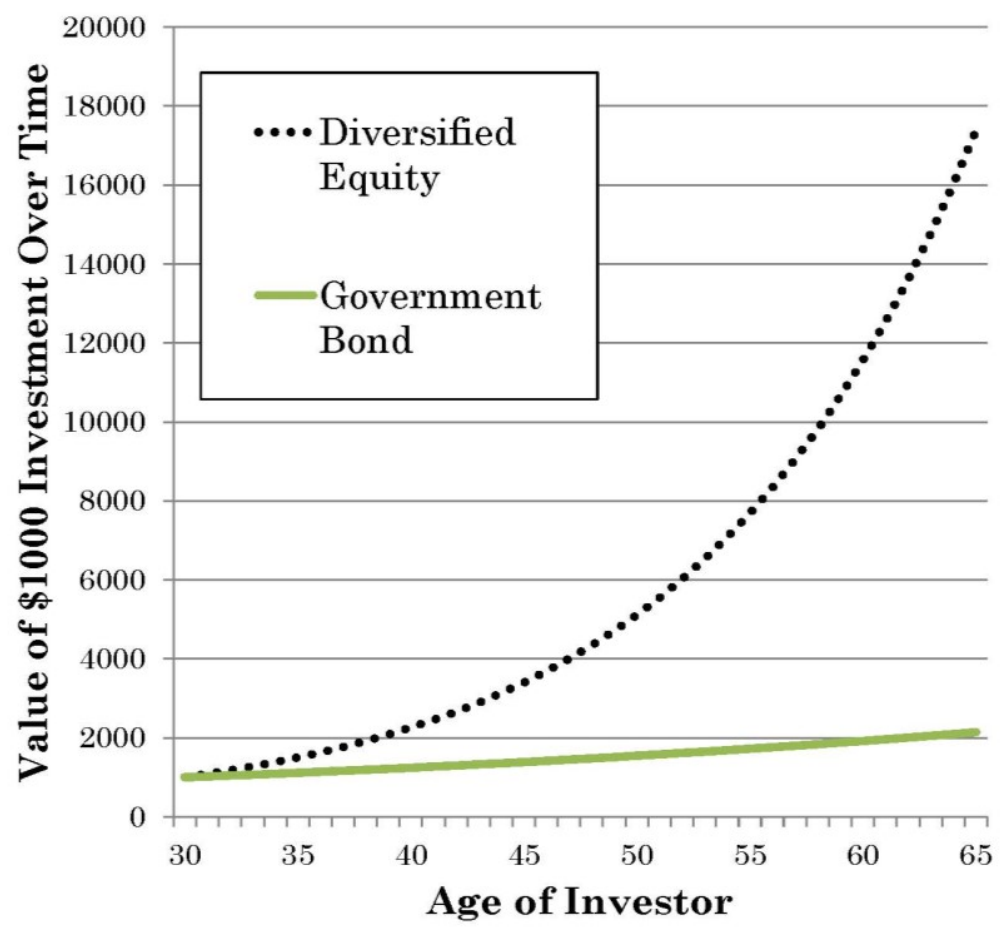

The same general point applies to the decision to opt out of the tax advantages of broadly diversified DC plans. Figure 3 depicts how large the economic penalty of electing to invest directly in stocks and not through tax-advantaged DC plans can be. ${ }^{72}$ While not as severe as the cost of avoiding equity altogether, the cost of trying to avoid the constraints of 401(k) plans

72 This figure uses conventional figures for expected equity returns and averages after-tax returns for taxable and tax-deferred accounts over the past twenty-five years, based on data and analysis from Munnell et al., supra note 62, at 5 (Table 4). It assumes a $6 \%$ expected pre-tax return, divided into $2 \%$ dividends and $4 \%$ capital gains. 
by investing directly in taxable accounts is still a draconian penalty, roughly equal to a third of the expected return on a standard equity investment. And this figure understates the penalty, because it excludes the "match" commonly given by employers for investments through DC plans, and only compares one investment at age 30 , rather than a more realistic stream of investments over time.

Figure 3: The Cost of Opting Out of Tax-Advantaged 401(k)

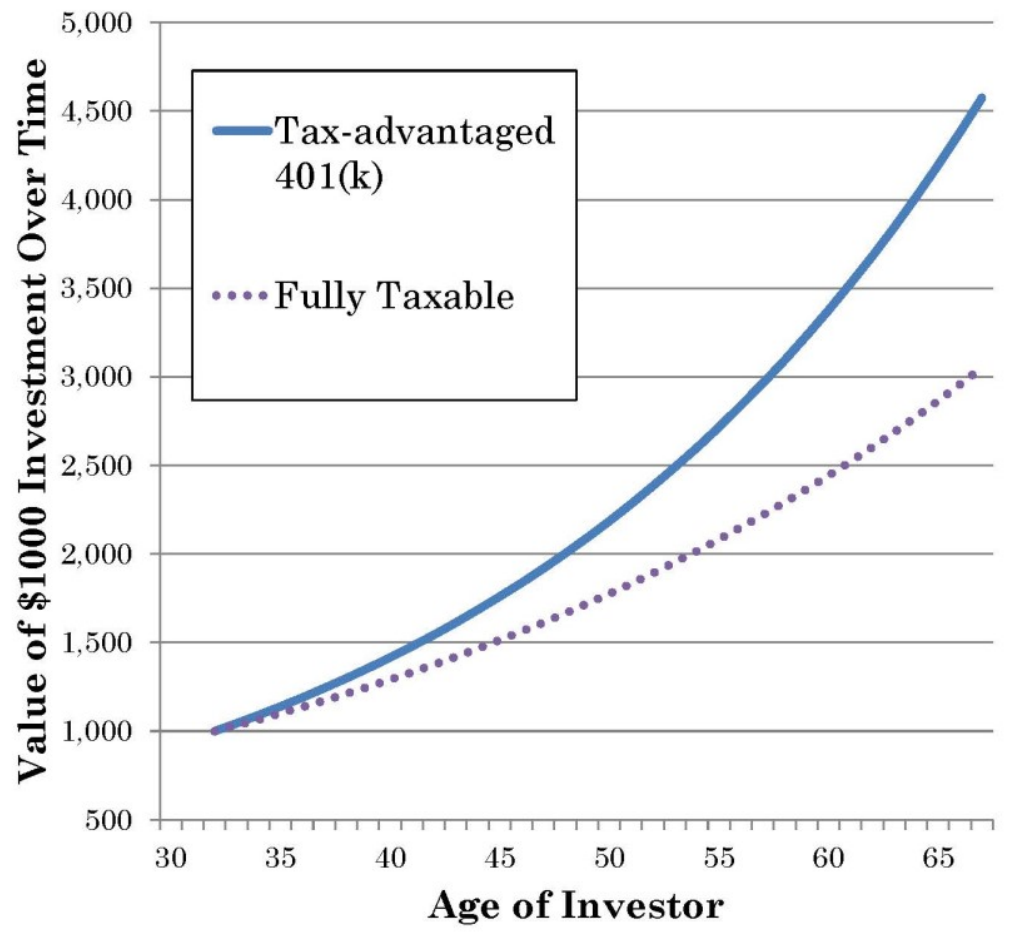




\section{CONCLUSION}

Amici urge careful consideration of the issues in this case for the reasons stated above.

Respectfully submitted,

ANNA-ROSE MATHIESON

Counsel of Record

BEN FEUER

CALIFORNIA APPELLATE LAW GROUP LLP 96 Jessie Street

San Francisco, CA 94105

(415) 649-6700

annarose@calapplaw.com

Attorneys for Amici Curiae

December 2017 